\title{
魚群内尾数がアユの遡上特性に与える影響 EFFECTS OF SCHOOL POPULATION ON MIGRATION CHARACTERISTICS OF AYU
}

\author{
鬼束幸樹 1 ・秋山壽一郎 2 ・関強志 3 ・高山輝貴 4 \\ Kouki ONITSUKA, Juichiro AKIYAMA, Tsuyoshi SEKI and Teruki TAKAYAMA \\ $1^{1}$ 正会員 博(工) 九州工業大学大学院准教授 建設社会工学研究系（下804-8550 北九州市戸畑区仙水町1-1） \\ ${ }^{2}$ フェロー会員 Ph.D. 九州工業大学大学院教授 建設社会工学研究系 \\ 学生員 九州工業大学大学院 工学府建設社会工学専攻博士前期課程 \\ 4 \\ 学生員 九州工業大学 工学部建設社会工学科
}

It has been considerably investigated on the factors that ayu are triggered migration from ocean to river. However, there are few studies that observed migration characteristics of ayu in the river. There is no collective view of migration characteristics of ayu in the river, because contradict observation results were obtained in the fishway. One of the reasons may depend on the school population, because ayu has a tendency to follow the swimming front ayu. In this study, the behavior of fish school of ayu in running water was analyzed. It was found that staying tendency increases with an increase of school population, so that the migration rate decreases with an increase of school population. The distance between each ayu decreases with an increase of school population. Further, it was found that the fluctuation of streamwise ground speed in upstream migration type is high and also that the fluctuation of spanwise ground speed in downstream migration type is high.

Key Words : school population, fish school radius, distance between individual fish, ground speed

\section{1.はじめに}

アユの遡上を誘発する因子は多数存在する. 以下では 各因子に着目してアユの遡上特性をレビューする.

アユが海洋から河川に遡上を開始する要因はかなり解 明されている．まず，海水温の上昇がアユの遡上を誘発 する ${ }^{1)}$. 遡上期のアユは前歷水温よりも $5^{\circ} \mathrm{C}$ 以上低い水域 を忌避 ( ${ }^{2}$ ，前歷水温程度の水域を選好するため ${ }^{3)}$ ，河口 域で待機していたアユは, 河川水温が海水温とほぼ等し くなると河川へと遡上を開始する ${ }^{4)}$.上記は月単位の挙 動であるが，日単位の挙動も解明されつつある．和田ら ${ }^{5}$ は特定の時間に遡上数が増加することを発見した．笹 らのおよび佐藤ら゚は上げ潮時に遡上量が増加すること, 和田 ${ }^{8}$ は低潮時よりも満潮時の遡上数が増加することを 解明した. また，上記の因子の関連性や影響の大きさも 解明されつつある9?.

次に, 河川に進入した後のアユの遡上特性に着目する. ところが，河川内でのアユの遡上状況を詳細に観察した 研究はほとんど無く, 京都府を貫流する宇川ではアユは
夜間に遡上せずに日中に遡上し，12〜16時に遡上数が最 大になることを解明した川那部ら ${ }^{10)}$ の研究以外は見あた らない，そのため, 河川内の中でも魚道という特殊な状 態で得られた遡上特性を参考にして河川内での魚の遡上 特性を推定せざるを得ない。

まず，時間と遡上数の関係に着目する．佐合ら ${ }^{11}$ は吉 井川に設置された大田原堰魚道において，13，16，19時 にアユの遡上数がピークになると述べた. 泉ら $\left.{ }^{12}\right)$ は赤石 第2頭首工魚道において，16〜18時に遡上数がピークに なると述べた。 福田ら $\left.{ }^{13}\right)$ は信濃川妙見堰魚道において, 午後にアユの遡上が集中し, 午前中はほとんど遡上しな いと述べた。しかし，川越ら ${ }^{14}$ は岩木川に設置された魚 道において8〜20時の間，ほぼ定常的に遡上寸ると述心゙ ている.

次に，水温と遡上数との関係に着目寸る. 平野ら ${ }^{15}$ は 五ヶ瀬川の岩熊井堰中央魚道において, 遡上数は 15 $20^{\circ} \mathrm{C}$ で多く, $17^{\circ} \mathrm{C}$ 前後でピークを示すと述べたが，川那 部ら ${ }^{10}$ は $17 \sim 18^{\circ} \mathrm{C}$ を越えた時にピークを示すと述べた.

続いて，濁度と遡上数との関係に着目寸る. 小田・今 
島 ${ }^{16)}$ は低濁度よりも高濁度の時に遡上数が増加すると指 摘した. ところが，小山・桜井 ${ }^{3)}$ が55〜 750ppmの間で3 種類の濁度に変化させた水と清流を同時に流してアユを 放流したところ，アユは清流を選択することを明らかに した。本田 ${ }^{2)}$ はさらに低濃度で実験を行い，アユは $15 \mathrm{ppm}$ 以上の水を忌避することを示した.

以上のように，河川中におけるアユの遡上特性につい ては統一的見解がほとんど得られていない。これは，ア ユの遡上に影響を及ぼす因子が，時刻，水温，濁度，

BOD, COD, 魚群内尾数等と複数存在するにも関わら ず17,18)，現地計測ではこれらの因子が同時に変化した状 態で遡上数をカウントすることに一因がある.この中で 魚群内尾数の変化が遡上特性に及ぼす影響についてはほ とんど解明されていない，一般に，アユには追随性があ るため, 魚群内尾数が変化すると群れの挙動も変化する と考えられる. 既往の研究で一日に観察された遡上数は, 福田ら ${ }^{13}$ が33尾, 佐合ら ${ }^{11}$ が102尾, 川越ら ${ }^{14)}$ が185尾, 泉ら ${ }^{12}$ が472および741尾, 平野ら ${ }^{15}$ が約10,000尾であり， 統一した結果が得られないのは, 遡上特性が水理および 水質の影響だけでなく，魚群内尾数によっても影響を受 けたことも一因と推定される.

本研究は開水路流中において，流速を一定にした状態 でアユの尾数を 1 ～10尾に変化させて魚群の挙動を解析 したものである.

\section{2. 実験装置および実験条件}

図-1に示すような長さ $4.0 \mathrm{~m}$, 幅 $B=0.8 \mathrm{~m}$, 高さ $0.2 \mathrm{~m}$ の 底面が白色で側壁が透明な水路を実験に用いた．流下方 向に $x$ 軸，鉛直上向きに $y$ 軸，横断方向に $z$ 軸をとる. 実験条件は表-1に示すように, 水深を $0.05 \mathrm{~m}$ に, 体長倍 流速を 10 で固定し, 用いるアユの尾数 $N$ を〜 10の範囲 で5段階に設定した. アユの平均体長 $\bar{B}_{L}$ は70 $\mathrm{mm}$ である 水路始端から $3.3 \mathrm{~m}$ 下流の水路中央 $(z / B=0.5)$ に直径 $0.25 \mathrm{~m}$ の円形金網を設置し, 所定の尾数のアユを挿入す る.アユを挿入して $5 \sim 10$ 秒馴致させた後に金網を取り 上げ，水路上部に設置した画素数 $1440 \times 1080$ ，撮影速度 $30 \mathrm{~Hz}$ のビデオカメラで撮影を開始する．全てのアユが 水路始端に到達, または全てのアユが水路終端から流出 した時に撮影を終了した．ただし，撮影開始から1分以 上経過しても水路内に魯群が定位している場合は1分で 撮影を中止した．上記の実験を各ケースで100回，合計 500 回行い, 計測後, 全てのアユの遊泳位置を $0.2 \mathrm{~s}$ ごとに 算出した．ただし，金網を取り上げた直後に1尾以上が 水路終端から流下してしまった場合は，魚が意図的に降 下したのではなく，金網を除去した影響で降下したと考

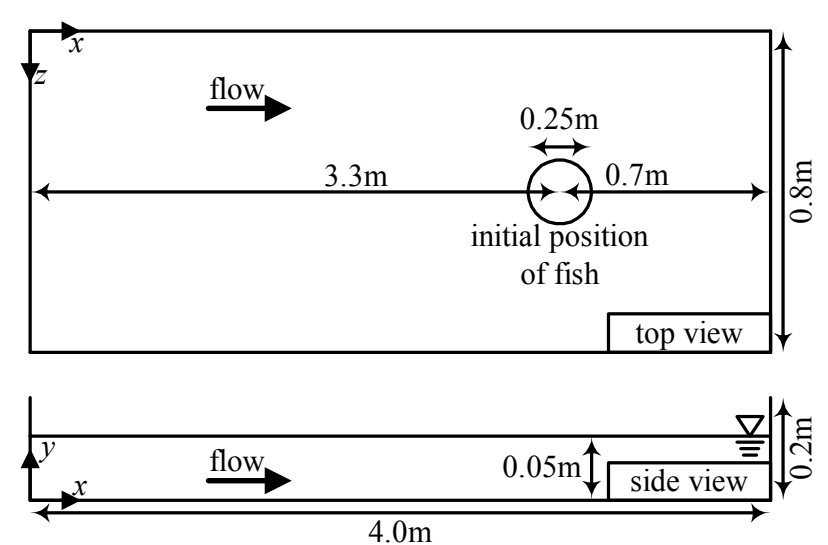

図-1＼cjkstart実験装置模式図

表-1 実験条件

\begin{tabular}{|c||c|c|c|c|c|}
\hline \multicolumn{1}{|c||}{$\bar{B}_{L}(\mathrm{~m})$} & \multicolumn{5}{|c|}{0.07} \\
\hline$h(\mathrm{~m})$ & \multicolumn{5}{|c|}{0.05} \\
\hline$U_{m} / \bar{B}_{L}(1 / \mathrm{s})$ & \multicolumn{5}{|c|}{10} \\
\hline$N$ & 1 & 2 & 3 & 5 & 10 \\
\hline
\end{tabular}

え, 解析から除外したため, 解析に用いたデータ数はア 二の尾数が1尾，2尾，3尾，5尾，10尾のとき，それぞれ 41個，71個，61個，73個，82個となった.

\section{3. 実験結果および考察}

\section{（1） 魚群挙動の分類}

観察の結果, 魚群の挙動は図-2に示寸5つのタイプに 分類されることが分かった.

a）魚群停滞タイプ(staying type)

流水中において初期尾数を維持した状態で魚群を形成 して遊泳しているが，対地速度がほぼゼロの状態で長時 間停滞しているタイプ.

b）魚群遡上タイプ (upstream migration type)

初期尾数を維持した状態で魚群を形成して遊泳し, 水 路上端まで遡上するタイプ.

c）魚群降下タイプ(downstream migration type) 初期尾数を維持した状態で魚群を形成して遊泳し, 水 路下端まで降下して流出するタイプ.

d）部分遡上タイプ(partial upstream migration type) 魚群を形成して遊泳し, 対地速度がほぼゼロの状態で 長時間停滞しているが，一部の魚だけが魚群から抜けだ し, 単独で水路上端まで遡上するタイプ.

e）部分降下タイプ(partial downstream migration type) 初期尾数を維持した状態で魚群を形成して遊泳し, 水 路下端まで降下して流出するが，一部の魚が水路に留ま るタイプ. 

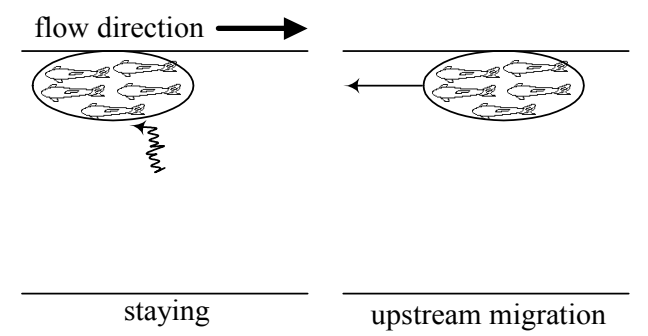
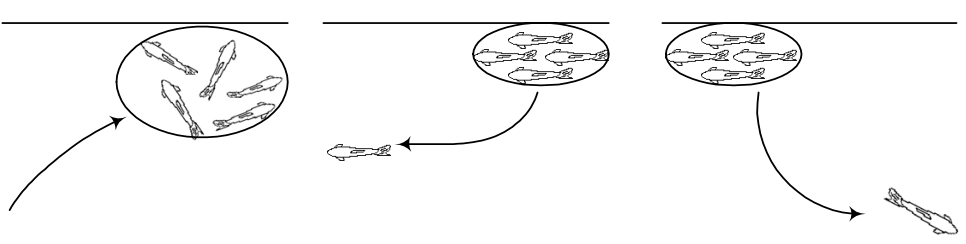

$\overline{\text { downstream migration }}$ partial upstream migration partial downstream migration

図-2 魚群の遊泳挙動タイプ

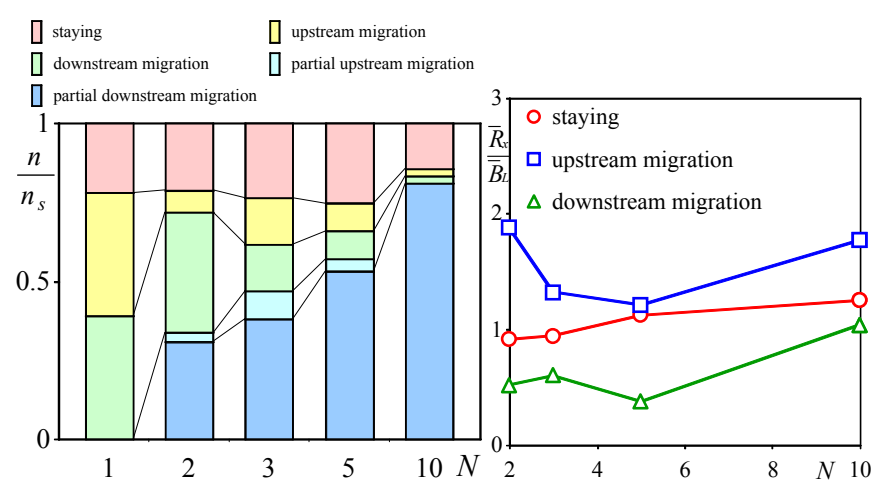

(a) $x$ 方向 図-3＼cjkstart各挙動タイプの割合

図-3に各実験ケースにおける各タイプ数 $n$ が有効実験 数 $n_{s}$ に占める割合と尾数 $N$ との関係を示す. 魚群遡上 率，魚群降下率は尾数の増加に伴い低下寸る．三宮ら ${ }^{19)}$ は静止流体中のタイリクバラタナゴの魚群内尾数が3尾 以上の場合，リーダーが存在せずに各個体間距離を一定 に保とうとすることを明らかにした。 また，尾数が増加 すると個体間距離を保つべき対象が増加し, 数尾が遡上 や降下を開始してもより多くの魚が存在する魚群に停滞 すると想定できる.したがって，本実験において尾数の 増加に伴って遡上率, 降下率が低下したと推測される.

部分遡上率はいずれのケースにおいても少ない.これ は上記のように魚群から単独で遡上を行う傾向が少ない ためと考えられる. 一方, 部分降下率については尾数の 増加に伴って急激に増加している。この理由については 後に考察する. 魚群停滞率は尾数による変化が余り見ら れない. しかし, 魚群停帯タイプと部分遡上タイプの違 いは，魚群から一部の魚が遡上するか否かであり，両夕 イプともほとんどの魚は群れに属して停滞している.し たがって, 両タイプを統合して考えると, 魚群内尾数の 増加に伴って魚群が停滞する傾向が強まるといえる.

\section{（2）各魚群タイプの形状}

初期尾数を維持した状態の魚群は, 魚群停滞, 魚群遡 上および魚群降下タイプなので，ここではこれら3つの タイプの魚群挙動を解析する.

石川 ${ }^{20)}$ の定義した魚群半径を2次元に拡張すると次式 となる。

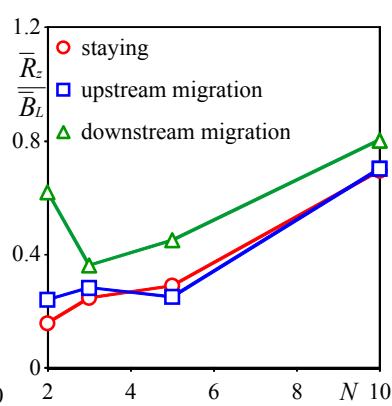

(b) z方向

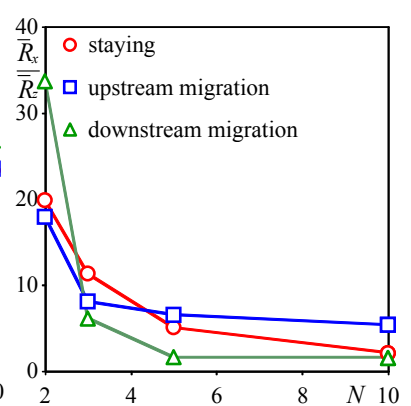

(c) $x$ と方向の比
図-4 魚群半径

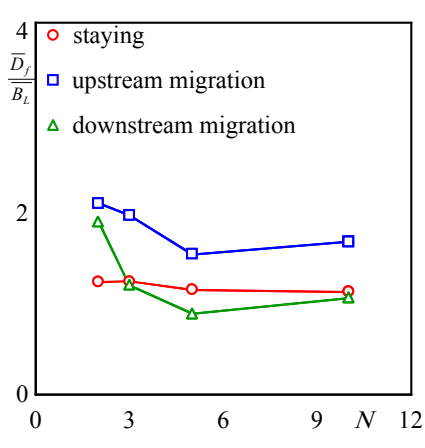

(a) 平均値

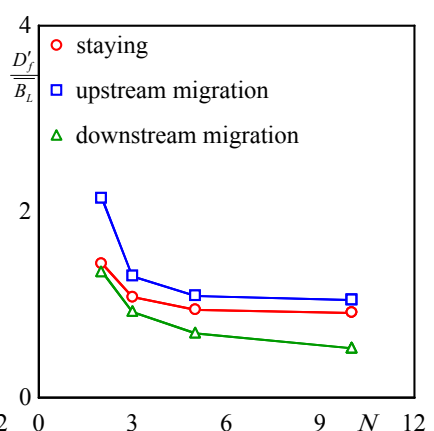

(b) 標準偏差
図-5 個体間距離

$$
\begin{gathered}
R_{x} \equiv \sqrt{\left.\sum_{i=1}^{N}\left\{x_{f i}-G_{x}\right)\right\}^{2} / N} \\
R_{z} \equiv \sqrt{\sum_{i=1}^{N}\left\{z_{f i}-G_{z}\right\}^{2} / N}
\end{gathered}
$$

ここに， $R_{x}, G_{x}, x_{f i}$ はそれぞれ $x$ 方向の魚群半径, 魚群重心の $x$ 座標, 任意 $i$ の魚の $x$ 座標であり, $z$ につ いても同様な定義である. 図-4(a)〜 (c) にそれぞれ有効 実験回数の平均值 $\bar{R}_{x}, \bar{R}_{z}$ を平均体長 $\bar{B}_{L}$ で除した值お よび両者の比 $\bar{R}_{x} / \bar{R}_{z}$ と尾数 $N$ との関係を示す. 図4 (a)より $\bar{R}_{x} / \bar{B}_{L}$ については魚群遡上が最も大きく魚群 降下が最も小さいことがわかる. 一方, 図-4(b)より $\bar{R}_{z} / \bar{B}_{L}$ については逆傾向である. よって, 図-4(c)に示 されるように，3タイプのいずれも $\bar{R}_{x} / \bar{R}_{z}$ は1以上の值 を示し流下方向に細長い形状をしているが，尾数が増加 
すると魚群遡上タイプは流下方向に細長い形状となり， 魚群降下タイプは円に近い形状となる. また魚群停滞夕 イプは両者の中間的な魚群形状を示寸ことが確認できる. 瞬間個体間距離 $\widetilde{D}_{f}$ は石川 ${ }^{20)}$ の定義に従い，各魚の間 隔を全て算出してその平均值とした. 従って, 10尾の場 合は45距離の平均となる. 各ケースにおいて実験時間で 時間平均值 $D_{f}$ を算出し, さらに, 有効実験数の平均值 $\bar{D}_{f}$ および標準偏差 $D^{\prime}{ }_{f}$ を算出し，図-5に3タイプの $\bar{D}_{f} / \bar{B}_{L}$ および $D^{\prime}{ }_{f} / \bar{B}_{L}$ を示した. 図-5(a)より，3タイ プにおける個体間距離が尾数の増加と共に減少傾向を示 すことが認められる. これは, 尾数の増加に伴い平均個 体間距離 $\bar{D}_{f} / \bar{B}_{L}$ を小さく寸る傾向があるためと考えら れる. タイプ別に比較すると, 魚群遡上タイプにおける 平均個体間距離が他のタイプよりも大きいことが確認さ れる.これは，魚群形状が流下方向に細長い形状である ことが原因である，一方，図-5(b)より個体間距離の標 準偏差はいずれのタイプでも尾数の増加と共に減少して いることが認められる. これは, 尾数が増加すると周囲 に位置する魚の数が増加するために, 自由に遊泳できる 範囲が減少したことによると考えられる. タイプ別に比 較すると, 魚群遡上タイプの值が大きく魚群降下タイプ の值が小さいことが認められる. 魚群逆上する場合は, 各個体が流水中で尾鯺を激しく摇らして遡上寸るため, 魚体の相対位置がぶれることが原因と考えられる. 魚群 降下の值が減少する理由については後に考察する.

\section{（3） 各魚群タイプの移動特性}

図-6 (a)，(b)に0.2sごとに求められた $x, z$ 方向の魚 群重心の瞬間刘地速度 $\widetilde{V}_{G x} / \bar{B}_{L}, \quad \widetilde{V}_{G z} / \bar{B}_{L}$ のヒストグラ ムをそれぞれ尾数別に示す. 図中には実験值から求めた 正規分布も示している. ここで, $\widetilde{V}_{G x}, \widetilde{V}_{G z}$ は上流方向 および右岸方向を正とした. 図-6(a) より魚群停滞タイ プは上下流に移動しているが，その平均值がほぼゼロで あることがわかる．鮘群遡上および魚群降下タイプは正 值および負值の両者を有するが，平均值がそれぞれ正お よび負であること，また魚群停滞タイプに比べてばらつ きが大きいことが観察される，一方，図-6(b)より，い ずれのタイプも左右にランダムに移動しているが，平均 值はほぼゼロであることがわかる．魚群降下タイプのば らつきが他の 2 タイプのものと比べて大きくなっている。

図-7(a)，(b)に $x, z$ 方向の魚群重心の平均対地速度 $\bar{V}_{G x} / \bar{B}_{L}$ および $\bar{V}_{G z} / \bar{B}_{L}$ を示寸. 当然, 魚群停滞タイ プの平均対地速度 $\bar{V}_{G x} / \bar{B}_{L}$ は全尾数でほぼゼロである 魚群遡上タイプおよび魚群降下タイプの平均対地速度 $\bar{V}_{G x} / \bar{B}_{L}$ の絶対值は尾数の増加と共に減少する. これ は, 尾数の増加に伴い周囲に位置する魚の数が増加する ため, 魚群中央の魚は遡上や降下を開始しにくくなるた
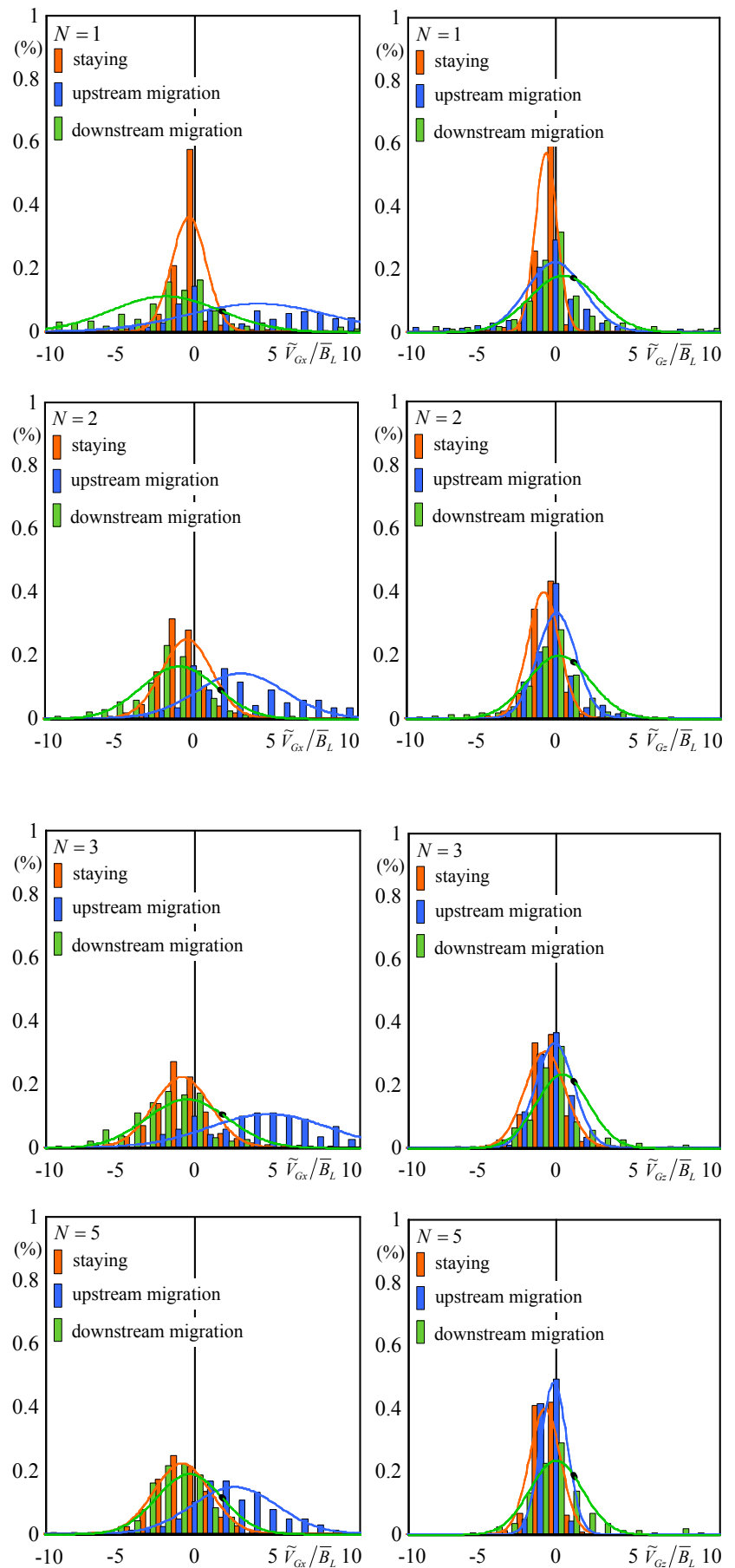

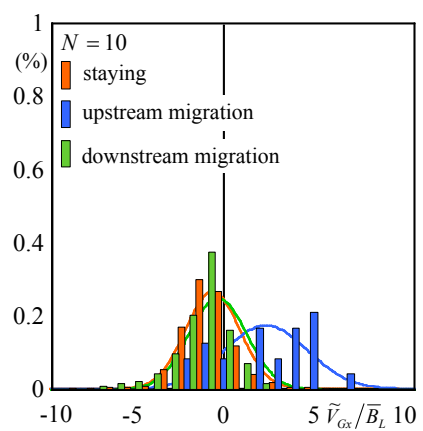

(a) $x$ 方向

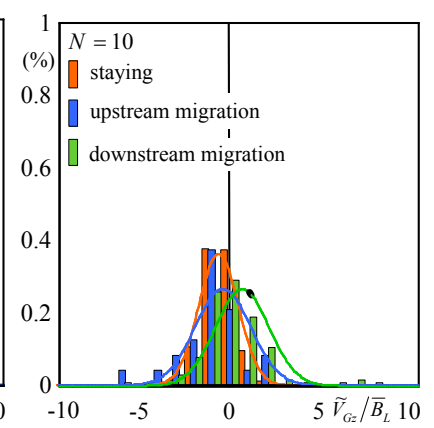

(b) z方向 図-6＼cjkstart瞬間対地速度ヒストグラム 


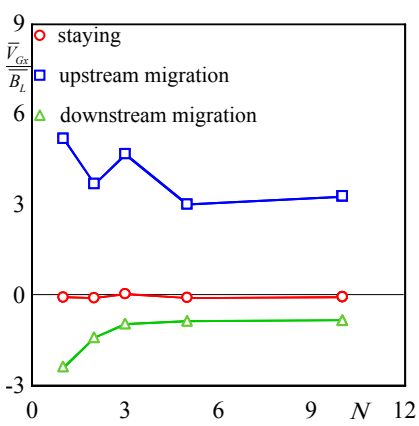

(a) $x$ 方向

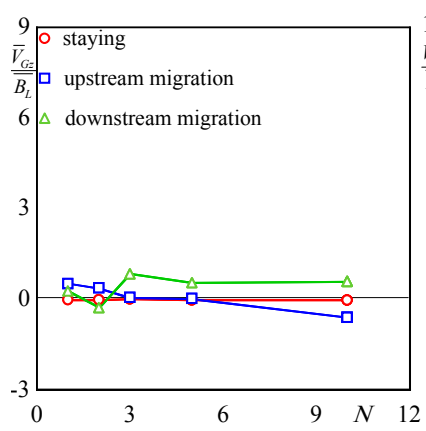

(b) z方向

図-7 平均対地速度

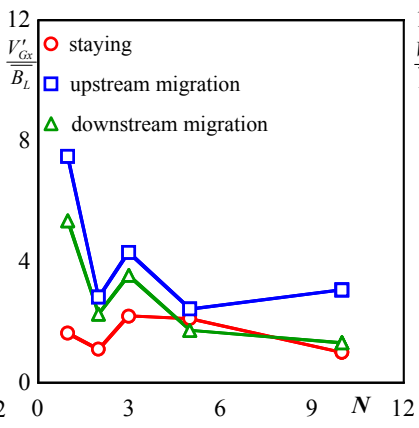

(a) $x$ 方向

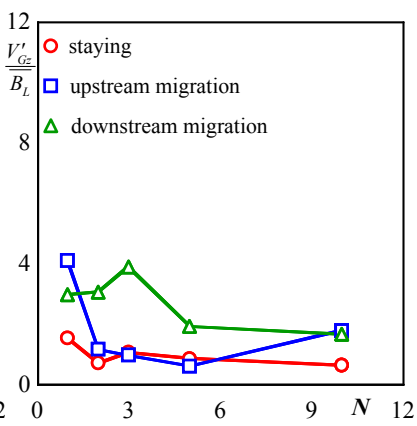

(b) z方向

図-8＼cjkstart対地速度の標準偏差
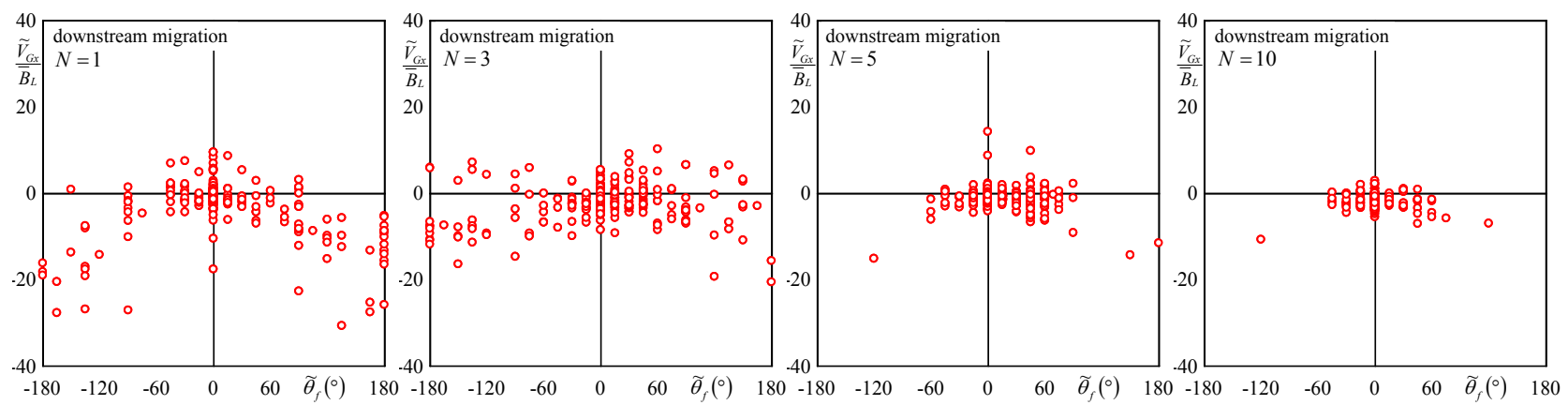

図-9 (a) 降下する直前の5秒間における瞬間魚向とx方向の瞬間対地速度との関係
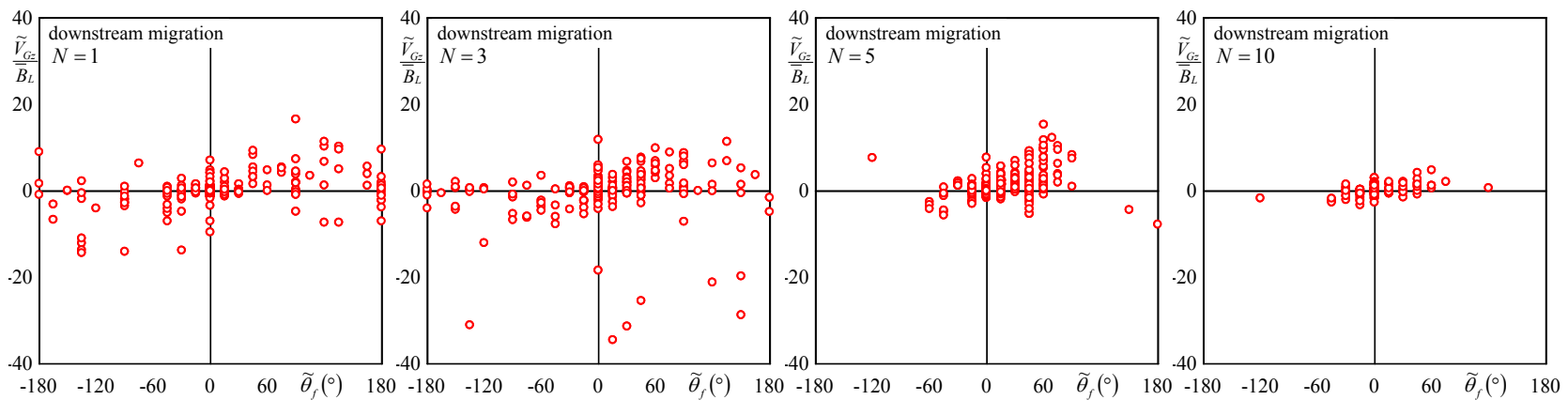

図-9 (b) 降下する直前の5秒間における瞬間魚向とz方向の瞬間対地速度との関係

めと想定される．また，個体間距離を一定に保とうとす るため，魚群に停滞する傾向が強まった結果と考えられ る. 一方，平均対地速度 $\bar{V}_{G z} / \bar{B}_{L}$ は多少のばらつきがあ るが，全タイプでもほぼゼロである.

図-8 (a)，（b)に $x ， z$ 方向の魚群重心の対地速度の標 準偏差 $V_{G x}^{\prime} / \bar{B}_{L}, V_{G z}^{\prime} / \bar{B}_{L}$ と尾数 $N$ との関係を示す. 魚群停帯タイプは両標準偏差共に小さな值を示す. よっ て，魚群は比較的流下方向にも横断方向にも変動せずに 停滞している。魚群遡上タイプは $V^{\prime}{ }_{G z} / \bar{B}_{L} よ り も$ $V^{\prime}{ }_{G x} / \bar{B}_{L}$ の值が顕著に大きく, 魚群降下タイプはその 逆となっている. したがって, 魚群遡上タイプは横断方 向にはあまり変動せずに上下流に大きく変動しながら遡 上している.この理由として，横断方向よりも流下方向 の乱れ強度が大きい21)ことが挙げられる. 乱れ強度が大 きいと, 各魚体位置が上下流に変動させられる. すると,
各魚体が選好する個体間距離から差違が生じる.この差 違を修正するために各魚は流下方向の速度調整を行う。 その結果，流下方向の標準偏差が大きくなると想定され る.しかし，魚群降下タイプが逆傾向となることを解明 するには，さらに魚群内の各個体の挙動を解明する必要 がある。

\section{（4）魚群降下タイプの特異性}

魚群の形状は，流水抵抗の低減を考慮すると図-4に示 した魚群遡上タイプのように，流下方向に細長い形状が 有利である。しかし，魚群降下タイプは，円形に近い形 状の魚群を形成し(図-4), 横断方向の対地速度が激しく 変動している(図-8). この理由を解明するために, 図一 $9(\mathrm{a}), \quad(\mathrm{b})$ に降下寸る直前の5秒間における瞬間魚向 $\tilde{\theta}_{f}$ と $x$ 方向瞬間対地速度 $\widetilde{V}_{G x} / \bar{B}_{L}$, および瞬間魚向 $\widetilde{\theta}_{f}$ と 
$z$ 方向瞬間対地速度 $\widetilde{V}_{G z} / \bar{B}_{L}$ との関係を示す. 図 -9 (a) より尾数が少ないときの瞬間魚向 $\widetilde{\theta}_{f}$ は広範囲であるの に対し, 尾数が増加すると $\widetilde{\theta}_{f}$ の範囲は狭くなる. また, 瞬間対地速度 $\widetilde{V}_{G x} / \bar{B}_{L}$ のばらつきも尾数の増加と共に減 少する. これは, 尾数の増加に伴い周囲の魚と同様な挙 動をとるからである。一方，図-9(b) より，いずれの尾 数でも右上がりの傾向を示寸ことがわかる. これは, 右 岸方向を向いた魚が右岸方向に，左岸方向を向いた魚が 左岸方向に移動していることを表寸，すなわち，魚が上 流向きから右岸あるいは左岸向きになったとき，流水の 運動量を受けるためにその方に移動することを意味す る.また，図-9(a)を見ると，瞬間魚向 $\widetilde{\theta}_{f}$ が $0^{\circ}$ からは なれるにつれて $\widetilde{V}_{G x} / \bar{B}_{L}$ が負值になっていることから， この時魚が下流に流されていることが理解される. 尾数 の増加に伴い, 図-9(b)における右上がり傾向からのば らつきが減少している. よって, 尾数の増加に伴い周囲 の挙動と同調するために, ある魚が魚向を変化させると 周囲の魚も同調する. すると, 流体の運動量を受けて下 流に流出寸ると考えられる.

\section{4. おわりに}

本研究は, 開水路流において体長倍流速を10で固定し, 用いるアユの尾数を 1 10の範囲で5段階に設定し, 魚群 行動の特性を解明したものである. 以下に結論を示寸.

(1) 魚群の挙動は, (1)魚群で停滞するタイプ, (2)魚群で 遡上するタイプ, (3)魚群で降下寸るタイプ, (4)魚群で遡 上するが一部の魚が水路に留まるタイプ，(5)魚群で降下 するが一部の魚が水路に留まるタイプ，の5つに分類さ れる.

（2）本実験条件下では尾数が増加すると魚群は停滞傾向 が強くなることが確認された。これは，各個体が魚群に 属した状態を好み，遡上あるいは降下を挑まないために 生じたものと考えられる.

(3) 魚群の遡上速度および魚群降下速度は尾数の増加に 伴い低下寸る. これは, 各魚が個体間距離を一定に保と うとするため, 魚群に停滞する傾向が強まった結果と考 えられる。

（4）魚群で遡上する際は流下方向に細長い形状となる. 一方，魚群で降下寸る際は横断方向の幅が増加する。こ の場合, 各魚の向きが流れと平行でなくなり, 流れの運 動量を受けて流出寸る.

\section{参考文献}

1) Tsukamoto, K. and Uchida, K.: Spacing and jumping behavior of the Ayu Plecoglossus altivelis, Nippon Suisan Gakkaishi, Vol.56, pp.13831392, 1990.

2) 本田晴朗 : アユの逆河行動におよぼす濁りおよび水温低下の影 響, 月干海洋科学, 第15巻, 第4号, pp.223-225, 1983.
3) 小山長雄, 桜井義雄 : 木兽三川河口資源調査報告書, 第2巻, p.129-134, 1965.

4) 堀田秀之 : 海産稚鮎の生態に於いて, 魚類学会誌, Vol.19, No.1, pp.15-20, 1953.

5) 和田清, 出水規行, 大堀文彦 : 長良川河口堰の魚道における塩 水遡上の動態と水生生物の生息分布・遡上行動に関寸る一考察, 河川技術論文集，第10巻，pp.423-428，2004.

6) 笹浩司, 後藤浩一, 実松利朗, 島田啓一, 井口謙, 和田清 : 長 良川中下流域における稚アユの遡上特性と遡上量調査の効率化 に関する一考察，河川技術論文集，第11巻，pp.453-458，2005.

7) 佐藤隆平, 菅原政一, 大塚勝章, 安藤淳一 : 鳴瀬堰付設階段式 魚道におけるアユ及びサケの遡上調査, 水産工学, Vol.29, No.2, pp.123-126, 1992.

8) 和田吉弘 : アユの溯上と魚道構造の関係, ダム技術, No.39, pp.34-42, 1990.

9) 永矢貴之, 白石芳樹, 鉒瀬明日香, 鬼束幸樹, 東野誠, 高見 徹, 東均, 秋山壽一郎, 小野篤志 : アユの遡上を誘発およ び阻害する環境因子の抽出と各環境因子間の関係，河川技 術論文集, 第15巻, pp.91-96, 2009.

10)川那部浩哉, 宮地伝二郎, 森圭一, 原田英司, 水原洋城, 大串 竜一 : 遡上アユの生態II, 京大生理生態業績, 第79巻, No.2, pp.145-167, 1956.

11)佐合純造，本多卓志，大木孝志，田中直也：大田原堰魚道にお けるアユの遡上実験報告, 水工学論文集, 第42巻, pp.493-498, 1998.

12)泉完, 高屋大介, 工藤明, 東信行 : 赤石川赤石第 2 頭首工のア イスハーバー型魚道における魚類等の遡上・水理特性, 農業土 木学会論文集, No.215, pp.75-84, 2001.

13)福田晴耕, 伊藤与之, 田部成幸, 稲川貢, 田中衛, 片野英喜 : 信濃川妙見堰における魚道調査, 第2回河道の水理と河川環境 シンポジウム論文集, pp.135-142, 1995.

14)川越信清, 泉完, 工藤明, 三上亘 : 頭首工魚道における魚介類 の遡上と水理, 弘大農報, No.61, pp.148-157, 1997.

15)平野克己, 岩槻幸雄, 三村文孝, 八木征雄, 尾田成幸 : 岩熊井 堰中央魚道におけるアユ遡上について, 水産増殖, 第44巻, 1 号, pp.1-6, 1996.

16) 小田光治, 今島要 : 魚悌二於厅儿魚悌遡上状況調査, 広島水産 試験, 第13巻, pp.133-153, 1936.

17) 中村俊六 : 魚道のはなし, 山海堂, 1995.

18）(財）ダム水源地環境整備センター編 : 最新魚道の設計, 信山社サイテック, 1998.

19) 三宮信夫, 島田亮, 中峯浩 : 魚群行動における自律分散機構 のモデリング，計測自動制御学会論文集，Vol.29，No.2， pp.211-219, 1993.

20)石川雅昭 : ウグイの魚群行動特性に関する実験的研究, 河川技 術論文集，第6巻，pp.101-106，2000.

21) Nezu, I. and Nakagawa, H.: Turbulence in Open-Channel Flows, IAHR-Monograph, Balkema, 1993.

(2010.9. 30 受付) 